\title{
The informal power configuration of local government and economic development policy in China
}

\author{
Mingxing Liu' ${ }^{1}$ Dong Zhang ${ }^{2}$ (D) Tao Qian $^{3^{*}}$ and Qi Zhang ${ }^{4}$
}

\author{
* Correspondence: \\ qiantaochew@sina.com \\ ${ }^{3}$ China Academy of West Region \\ Development, Zhejiang University, \\ Hangzhou, China \\ Full list of author information is \\ available at the end of the article
}

\begin{abstract}
The spatial variation of local economic policies in Zhejiang province from the 1950s to 1990s can be traced back to the communist revolution prior to 1949. We argue that the revolutionary history shaped the informal power configurations at the county level in Zhejiang province, which in turn determined the attitudes of local officials toward capitalist developments in both the Maoist and reform eras. More specifically, if a particular locality had established local guerrillas, local officials were motivated to protect local economic interests and facilitate economic development for the sake of political survival. After the field armies took over Zhejiang province, local cadres with guerrilla backgrounds were marginalized in politics and thus were compelled to mitigate the vulnerability to potential attacks through garnering support of grassroots cadres and the masses. We test our hypothesis by using Zhejiang province county-level data from 1952 to 1998.

Keywords: Revolutionary legacy; Informal politics; Power configuration; Economic policy
\end{abstract}

\section{Background}

China's economic transition has been remarkable in terms of economic growth brought about by the past decades of reform and opening up the market. China has transformed itself from a centrally planned economy to an emerging market economy, and the development of the private sector is not only reflected in its scale but has also undergone an impressive transformation of ownership structure (Tsai 2006). How is it possible that the private economy has emerged and experienced such high growth in an authoritarian regime like China?

The existing literature on authoritarian regimes suggests three mechanisms that can explain the puzzling outcome of high growth in authoritarian regimes. One can raise both theoretical issues as well as issues with their applications to the case of China using all three of these mechanisms. McGuire and Olson (1996) and Olson (1993) argue that dictators who keep the long-term horizon in mind have sufficient incentive to provide good governance because they expect to receive much of the gains from economic growth. Yet, the underlying assumption of a unified leadership in this model appears to be questionable because dictators generally face formidable challenges within the ruling bloc or from external threats (Svolik 2009; Wintrobe 1998).

(C) 2015 Liu et al. Open Access This article is distributed under the terms of the Creative Commons Attribution 4.0 International License (http://creativecommons.org/licenses/by/4.0/), which permits unrestricted use, distribution, and reproduction in any medium, provided you give appropriate credit to the original author(s) and the source, provide a link to the Creative Commons license, and indicate if changes were made. The Creative Commons Public Domain Dedication waiver (http://creativecommons.org/publicdomain/ zero/1.0/) applies to the data made available in this article, unless otherwise stated. 
Taking into account the internal and external threats, the second approach highlights the role of quasi-democratic institutions, including political parties, legislatures, and elections, in co-opting elites and empowering broader social forces (Magaloni 2008). These nominally democratic institutions embedded in authoritarian regimes arguably serve to impose self-constraint on the rulers and constitute a credible commitment to prospective investors and taxpayers, ultimately boosting economic growth (Gandhi 2008; Gehlbach and Keefer 2011; Wright 2008). Unlike democracies, however, authoritarian regimes can hardly make credible long-term commitments, in part because of grave succession problems.

One strand of literature suggests that de facto fiscal federalism in the reform period encouraged local government to provide favorable environments for investors so as to enhance local revenue (Qian et al. 1995). Many of these works focus on fiscal decentralization to understand local governments' incentive to develop a private economy. For example, Qian and Xu (1993) emphasize decentralization as the institutional basis of the development of the Chinese private economy, especially the development of township and village enterprises (TVEs). In addition, Qian and Roland (1998) believe that fiscal decentralization and the consequent competition between local governments partly solved the problem of soft-budget constraint. Oi (1992) proposes the analytical framework of "local state corporatism," pointing out that obtaining fiscal revenue motivates local governments to support TVEs.

In the context of economic decentralization, scholars have devoted a great deal of attention to concrete institutional designs at the local level. From the perspective of the property structure of private enterprises, Li (1994) highlights the effectiveness of ambiguous property rights under an imperfect market. Weitzman and $\mathrm{Xu}$ (1994) argue that the ambiguity of property rights of TVEs is based on a cooperation culture that resulted from multistage games. Che and Qian (1998) point out that local governments' control of TVEs can effectively constrain the predatory behavior of the state when institutionalized property rights protection is absent.

Nevertheless, as Cai and Treisman (2006) argue, the Chinese Communist Party's (CCP) top-down power structure and the soft-budget constraint faced by local authorities likely diminished the impact of fiscal federalism. In addition, Nee (2000) believes that the driving force of the Chinese economy's successful reform lies in the success of market transformation rather than the commitment of local governments to economic development. Peng (2001) argues that it is the indirect supervision of markets rather than the direct supervision of governments that reduced the principal-agency costs of TVEs. ${ }^{1}$ Despite these arguments against fiscal federalism, local authorities in some parts of China, especially places like Zhejiang and Fujian, actively protected local businesses even during the Maoist period. Why did some local officials protect property rights while others did not?

In reality, there are significant regional variations in the size, performance, and ownership structure of private economic development. More importantly, these differences emerged as early as the Mao era. Most of the existing literature treats the third plenary session of the 11th Party Congress in 1978 as the starting point for analysis and pays scant attention to the evolution of policies on the non-state-owned economy prior to 
1978. Putterman (1997) highlights the linkages between the development of commune and brigade enterprises before the reform to that of TVEs after the reform. At the beginning of the reform, the regions that had potential for developing TVEs were basically those areas that had established relatively successful commune and brigade enterprises. Why did some local political leaders protect the development of the nonstate-owned economy during the Maoist period? Apparently the arguments that highlight the role of marketization cannot explain this phenomenon. The motivation of local governments at the micro level is important in understanding the rise of the nonstate-owned economy prior to 1978. Because the tenure of local government officials is generally short, they tend to be "roving bandits" and play the role of "grabbing hands," thereby implementing policies that extract resources rather than protect markets (Olson 1993). What mechanism, then, restrained these "grabbing hands"? If such a mechanism exists, why does its effect vary so considerably across different regions of China?

\section{Zhejiang province as the analytical subject}

To answer the above questions, we examine the historical origins of private economy development and economic policy making at the county level in Zhejiang province, which has the most developed private sector in China. The academic debates on the historical causes of Zhejiang's private economy have been substantial (e.g., Shi et al. 2004a, 2004b). ${ }^{2}$ For instance, Liu (1992) points out that the revolutionary legacy of Wenzhou is the key to understanding the emergence of the private economy: The local guerrillas of Wenzhou were relatively independent before 1949; they had loose ties to party elites at the central level but had established close ties to the local people of Wenzhou. In addition, local guerrillas were involved in the liberation war in Wenzhou such that they were better able to effectively control the local government. In addition, because of their close relationship to the local people, these guerrillas had the incentive to selectively implement policies from higher-level officials and shelter the development of the private economy. ${ }^{3}$

Liu (1992) provides an important analytical lens for the informal politics of local government in China but assumes that local cadres who were originally local guerrillas (hereafter referred as "guerrilla cadres") could effectively protect the interests of local people due to their close relationship. However, there were many revolutionary base areas outside of Zhejiang province. Why did the local cadres in Wenzhou protect the market and develop the private economy, while local cadres in other regions failed to do so? In addition, Liu (1992) pays scant attention to the informal political network in which the guerrilla cadres in Wenzhou were embedded after the liberation, especially their informal ties to higher-level political elites. Local cadres who were marginalized did not necessarily circumvent the radical policies issued by higher-level governments; instead, they might pander to higher-level governments to escape a disadvantageous situation. As long as the power of higher-level governments was strong enough, it is doubtful that lower cadres dared to risk resisting their policies. Moreover, a selective implementation of policies does not necessarily mean that grassroots cadres would implement policies favored by the local people. O'Brien and Li (1999) point out that the grassroots cadres selectively enacted "bad" policies for their own interests rather than "good" ones. Therefore, we cannot assume that local economic policies always 
tend toward a "good" direction while ignoring the existence of those "bad" institutions; powerful elites may create policies to protect their own interests (Acemoglu 2006). Finally, the guerrilla cadres' ability to control local governments was not solely determined by the strength of military forces that liberated counties in 1949. Unlike Wenzhou, areas such as Ningbo and Jinhua were liberated by the field armies yet they developed vigorous private economies.

From the perspective of informal power configuration, this article explores the regional variations on how local economic policies were enacted and private economies developed. In China, local governments have similar formal political institutions to each other but differ in the informal political power configuration. The term "informal power configuration" refers to the informal political networks among political elites and their impact on the allocation of de facto political power. ${ }^{4}$

The most crucial goal for local cadres is to ensure their political survival. This goal is sometimes compatible with but sometimes also in conflict with the incentive to protect property rights because good policies can threaten political survival but bad policies can consolidate political survival (Bueno de Mesquita et al. 2003). ${ }^{5}$ We argue that the political power configurations in which local cadres were embedded determined their motivation. In a centralized political system, higher-level officials have the power to appoint and remove a subordinate official. Therefore, local officials are expected to be more inclined toward satisfying the needs of their superior officials rather than protecting the interests of grassroots cadres and the masses. What kind of political power configurations led local cadres to distribute benefits to their subordinate officials or the masses? Drawing on the history of Zhejiang province, this article addresses this question from the logic of political survival, which is briefly summarized below.

First, power conflicts among political elites are always present in politics. Local officials can secretly or even openly encourage grassroots cadres and the masses to accuse their competitors at higher-level authorities based either on formal rules or politicized excuses in line-struggle (路线斗争) (this kind of power struggle appeared more frequently prior to the 1990s in China). If a local cadre lacks support from his subordinate officials, then his political rivals can easily attack him in a power struggle. Because of the constant power conflicts under authoritarian regimes, local cadres need support from both higher-level officials and their subordinates in order to ensure their long-term political survival. Nevertheless, power conflicts do not necessarily lead to policies protecting the interests of grassroots cadres. ${ }^{6}$ What happens more frequently in reality is that local cadres are preoccupied with distributing benefits to their key supporters while ignoring the interests of the masses.

In the presence of political conflicts, if local cadres have formed close informal ties with officials at higher authorities, they are less likely to face political attacks, especially severe attacks. Therefore, they have a strong motivation to implement the policies favored by their patrons at the higher authorities. Likewise, they have little incentive to win support from subordinates and implement policies that can protect the interests of the masses. On the contrary, if the informal ties between local cadres and superior officials are loose, local officials are at a serious disadvantage when it comes to power conflicts. In particular, if there are close informal ties among local cadres, they could be attacked or purged as a group by political rivals. Under these circumstances, local cadres have a strong motivation to pursue policies that can protect local interests. 
Therefore, neither the close relationship between local cadres and the masses nor "benevolent" rule can account for the emergence of "good" policies. Instead, local cadres protect the economic interests of the masses because they are concerned with potential attacks launched by their political rivals.

More importantly, local cadres are more likely to be attacked by political rivals if they lack political support from the masses and grassroots cadres. Under China's political system, higher-level officials are unable to unilaterally launch large-scale purges of certain kinds of officials. In order to achieve their goals, they must take advantage of political movements launched by the party center and mobilize grassroots cadres and the masses to denounce their political rivals. Thus, if the cadres have broad political support from grassroots cadres and the masses, it is difficult to purge them through political movements. Moreover, they can take advantage of the mass movements to mitigate the pressure from power conflicts.

To ensure long-term political survival, it is the rational choice for local cadres to protect the interests of grassroots elites. Of course, the extent to which local officials can implement economic policies to protect local economic interests depends on the window of opportunity provided by the central government. In most cases, local cadres are unable to publicly refuse to implement central government's policies, yet they can try to flexibly implement these policies.

With regard to the history of economic development in Zhejiang, we argue that the revolutionary legacies shaped different informal political power configurations of the counties in Zhejiang. In areas that had established local guerrilla forces before the liberation, local cadres were influential at the grassroots level but had loose informal ties with their superiors-cadres who came to southern China during the liberation war (hereafter referred to as "southbound cadres" and thus were always dealing with political pressure from the southbound cadres. They were motivated to implement policies that protected the economic interests of the masses for their own political survival. During the Cultural Revolution, the mass movements undermined the political influence of the southbound cadres. In 1970, the central government began to encourage local governments to develop rural industry, creating greater policy autonomy for local cadres. The policy foundation of protecting private property rights before the 1980s persisted into the reform era and led to the divergence of economic development across counties in Zhejiang.

The revolutionary legacy and the configuration of political power in Zhejiang province After the Chinese Communist Party (CCP) was founded, party branches in Zhejiang province mushroomed during Kuomintang (KMT)-CCP cooperation in the 1920s. However, party branch development dwindled in the aftermath of 1927's April 12th Counter-Revolutionary Coup. During the 3-year guerrilla war, local revolutionary forces in Zhejiang were unable to contact the party center. As the Sino-Japanese War broke out, provincial-level party organizations of Zhejiang were restored, yet in early 1942, the Wenzhou office of the Zhejiang provincial party committee was completely destroyed and Liu Ying and other party leaders were executed. At that point, the guerrillas in southern Zhejiang fought independently during the Sino-Japanese war. In order to strengthen party leadership in Zhejiang province, the party center and the 
Central China Bureau of the CCP established the Eastern Zhejiang Anti-Japanese Base Area (浙东抗日根据地). Nevertheless, by the end of the Sino-Japanese war, the New Fourth Army had retreated to north of the Yangtze River. As a consequence, the connection between the military forces of eastern Zhejiang and their higher-level party organizations had been weakened.

During the Liberation War (1946-1969), the guerrilla forces in Zhejiang were concentrated in eastern and southern Zhejiang: the Eastern Zhejiang Guerrilla (浙东游击队) was active in Ningbo, Jinhua, and Shaoxing, while the Southern Zhejiang Guerrilla (浙南游击队) had great influence in Wenzhou and Taizhou. In 1949, Zhejiang province was liberated by the Second Field Army and the Third Field Army; the Second Field Army contributed to liberating southwestern Zhejiang, while the Third Field Army primarily liberated the northern and eastern parts of Zhejiang. There was almost no fierce fighting in the course of liberating Zhejiang other than in the Quzhou area of southwestern Zhejiang and some islands. During this period, the guerrillas in Zhejiang performed remarkably, independently liberating 24 counties. After the Liberation War, the cadres accompanying the field armies took office in all levels of governments in Zhejiang province. It is worth noting that the main force of the Second Field Army in Zhejiang marched to Sichuan and Guizhou after Zhejiang was liberated; thus, the government officials in Zhejiang province were either from the Third Field Army or local guerrillas. The southbound cadres from the Shandong Revolutionary Base Area marched to Zhejiang with the Third Field Army and filled many key positions in various levels of Zhejiang's government. ${ }^{7}$ In short, the southbound cadres from the field armies and local cadres from guerrillas were the two political forces that influenced policy making in Zhejiang.

In general, provincial party committees serve as the highest decision-making body at the provincial level. Provincial party standing committees have great influence on the distribution of political and economic resources within a province. By analyzing the background information on members of the provincial party standing committees, we can better understand the political power configuration of Zhejiang province.

We focus mainly on two types of provincial party standing committee (PPSC) members who had revolutionary experience prior to 1949: one group of cadres had revolutionary experience in Zhejiang for at least 1 year before 1949 (most were local guerrillas); the other group consisted of southbound cadres from the Third Field Army. As shown in Fig. 1, southbound cadres dominated the PPSC until the mid-1980s. In contrast, cadres from local guerrillas were marginalized and only Yang Siyi (then vicegovernor of Zhejiang) took a seat in PPSC. Yang was a former party secretary of Zhuji County during the Sino-Japanese War and founded the Jin Xiao Guerrilla Branch. The southbound cadres also played a dominant role in county-level and prefecture-level governments. $^{8}$

Starting in the 1970s, a number of cadres who had no revolutionary experience before 1949 gradually took positions in the PPSC. Figure 2 shows the share of local cadres with no revolutionary experience in the PPSC over time. Here, the term "local cadres" refers to those who had more than 1 year of experience at the county or township level of government ${ }^{9}$ before they were promoted to PPSC membership. As shown in Fig. 2, in the mid-1990s, local cadres with no revolutionary experience occupied more than 


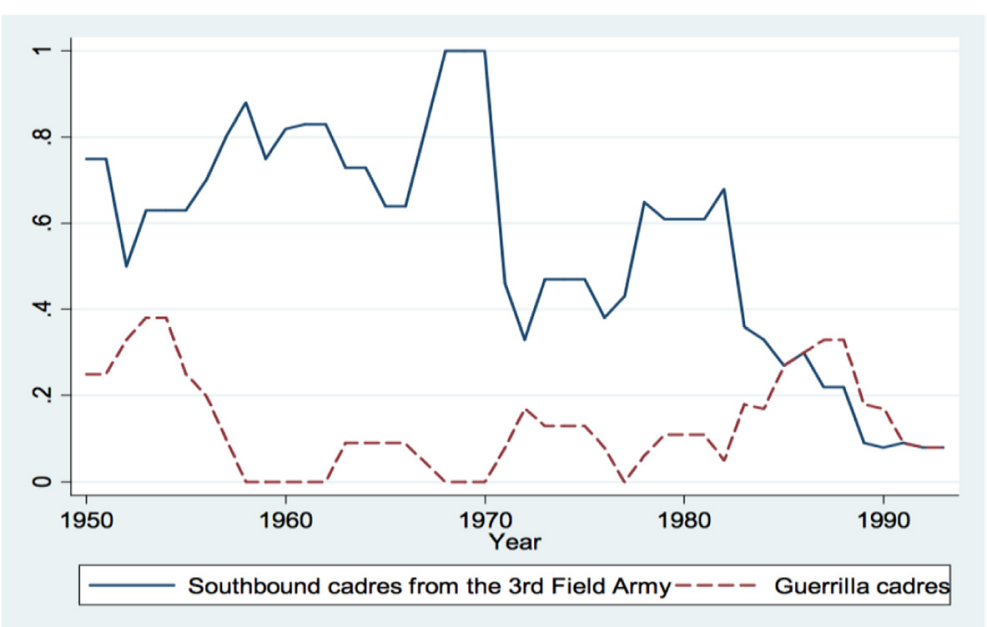

Fig. 1 The change in membership composition of the provincial party standing committee (PPSC) in Zhejiang province. Source: the CCP organization history of Zhejiang province (edited by the CCP organization department of Zhejiang province, 1994); biographies collected by authors

half of the seats in the PPSC, yet most of these local cadres were not in guerrilla counties before $1949 .{ }^{10}$ In fact, from 1970 to 1997 only three cadres came from guerrilla counties.

Since the early 1950s, power struggles occurred between the southbound cadres and the guerrilla cadres in Zhejiang. For example, the Southern Zhejiang Guerrilla had formed the leadership in some counties before southbound cadres took over and were reluctant to incorporate southbound cadres into local party committees and local governments. In the name of antifactionalism and antilocalism, the Zhejiang provincial party committee removed the key leaders of the Southern Zhejiang Guerrilla. During the Anti-rightist Movement in the 1950s, local cadres with guerrilla backgrounds were further attacked and purged from all levels of CCP committees and governments (Foster 1997, 191-232). ${ }^{11}$

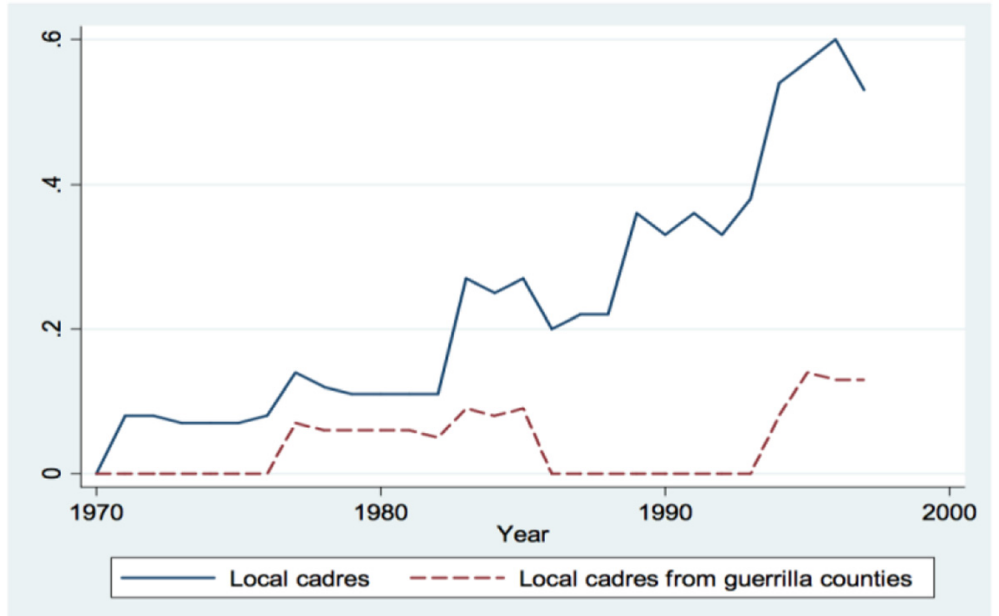

Fig. 2 The share of local cadres with no revolutionary experience in the PPSC. Source: the CCP organization history of Zhejiang province (edited by the CCP organization department of Zhejiang province, 1994); biographies collected by authors 
After southbound cadres took control of local governments in some counties with a weak guerrilla tradition such as Lishui County, they promoted a large number of young cadres during the land reform (referred to as "land reform cadres," 土改干部) to replace guerrilla cadres. However, in counties with strong guerrilla forces such as Yueqing, Cixi, Wenling, or Jinhua, the majority of cadres at the grassroots level were from local guerrilla forces. Our study suggests that due to their marginalized positions in local politics, local cadres with guerrilla backgrounds were forced to adopt policies that protected the local interests, hoping to win the support of the grassroots elites. It is worth noting that although the land reform cadres were local cadres, they were more likely to implement policies favored by high-level officials because their power derived from higher-level governments. In addition, informal ties among land reform cadres were weak such that they were unable to take collective actions as guerrilla cadres.

Although guerrilla cadres tried to mitigate the negative effects of "leftist" economic policies behind the scenes, they were forced to publicly comply with these policies in the 1950 s and 1960s, given the dominant role of southbound cadres in local authorities. Precisely because guerrilla cadres protected the interests of grassroots elites and maintained a good relationship with the masses, they were more insulated from mass movements during the Cultural Revolution (CR). In contrast, the influence of southbound cadres was largely weakened during the CR. Beginning in the 1970s, the relative de facto power of southbound and guerrilla cadres shifted in local governments. Although southbound cadres still played a major role in county-level and city-level governments, the political influence of guerrilla cadres began to increase.

\section{Economic policies of local governments of Zhejiang}

\section{The household responsibility system during the agricultural collectivization}

In the wave of agricultural collectivization, the local cadres of Zhejiang did not blindly follow the radical policies set by the higher authorities. In the spring of 1956, some agricultural cooperatives of Yongjia County experimented with the production responsibility system in which production was contracted to communes with full awards and full compensation (Agricultural Bureau of Yongjia County 1997, 122). In May 1956, the county leaders of Yongjia decided to pilot the production responsibility system below the team level in Liaoyuan Commune, pushing forward the system of "three contracts to teams (三包到队), responsibility to individuals (责任到人), fixed quotas to mounds (定额到丘), and unified management (统一经营).” In September 1956, the CCP Committee of Yongjia requested all districts and townships to adopt rural household responsibility systems. By June 1957, the peasants under the household responsibility system in Yongjia accounted for $42 \%$ of total commune members. In Wenzhou, more than 1000 communes adopted the household responsibility system, accounting for $15 \%$ of total commune members (Party History Research Center of CCP Yongjia County, Agricultural Bureau of Yongjia County, and Archival Bureau of Yongjia County coedited, Agricultural Bureau of Yongjia 1994, 21).

The pilot experiments of the household responsibility system in Yongiia generated intense debates within Zhejiang province and were eventually vetoed by the central 
government. On March 8, 1957, Yongiia followed provincial and prefectural directives and abolished the household responsibility system in all communes except the Liaoyuan Commune. During the rectification campaign (整风运动) and the Anti-Rightist Campaign (反右运动), Yongiia's household responsibility system was denounced in Zhejiang province and a number of cadres, including the key leaders of the county, were stigmatized as "rightists" (右派).

Although the reform of the household responsibility system in Yongjia appeared to end in failure, the household responsibility system did not in fact die out in Yongjia and other places in Wenzhou. Many rural areas of Wenzhou, especially mountainous or semi-mountainous villages, merely followed agricultural collectivization policies on the surface and secretly adopted the household responsibility system. This practice became more apparent after the Cultural Revolution. In 1968, 5432 production teams embraced the household responsibility system reform in Yongjia, accounting for $77.32 \%$ of the county's total production teams. In 1976, the number exceeded 6000, accounting for more than $80 \%$ of the total production teams (Codification Committee of Local History of Yongjia County 2003, 465-66).

During the Sino-Japanese War, Yongjia served as the base area for the Yongyue People's Anti-Japanese and Self-defense Guerrilla (永乐人民抗日自卫游击纵队). During the Liberation War, Yongiia was the major area influenced by the Kuocang Branch of Southern Zhejiang Guerrilla (浙南游击纵队括苍支队). Field interviews in Yongjia and Yueqing revealed that many grassroots cadres who had guerrilla experience played a critical role in the acquiescence and even promotion of the household responsibility system. They had a relatively strong capacity to act collectively with peasants while avoiding accusation from one another within villages, which allowed the household responsibility system policy to continue in secret. In addition, because guerrilla cadres did not implement radical leftleaning policies, no severe famine occurred in the villages of Yongjia during the Great Leap Forward. As a consequence, guerrilla cadres won broader political support from the masses and grassroots cadres.

\section{Withdrawing from communes during the agricultural collectivization}

In the course of establishing advanced agricultural cooperatives, withdrawing from communes became a nationwide phenomenon ( $\mathrm{Du}$ 2005, 84). Many counties in Zhejiang forced peasants to join communes and implemented the policy of “grasping two sides and mobilizing the middle" (抓两头, 带中间) relying on poor peasants, fighting against rich peasants, and mobilizing middle peasants, and many peasants joined communes in an uneasy frame of mind (Bo 1991, 331). Meanwhile, a series of production and distribution problems brought by advanced communes jeopardized the interests of peasants. In many areas, peasants protested and called for leaving their communes (闹退社). In 1957, as many as 200,000 households withdrew from communes in Zhejiang province, accounting for $4.3 \%$ of peasants in communes; 1400 cooperative communes subsequently collapsed. The rate of quitting communes was relatively high in Ningbo (11.81\%), Wenzhou (5.52\%), and Jinhua (1.85\%) (Ye 2003).

Ningbo was the region with the highest rate of quitting communes. According to the Rural Work Department of the CCP, in 1956, $5 \%$ of households had already withdrawn from communes in Ningbo, with another $20 \%$ intending to 
quit (The Office of the Agricultural Committee of China 1981, 655). In the 345 cooperative communes of Cixi, 3084 households made requests to leave their communes (Codification Committee of Local History of Cixi City 1992, 218). In 1957, tens of thousands of peasants in 21 towns and 172 cooperative communes asked to quit their communes in Yuyao (Codification Committee of Local History of Yuyao County 1993, 183). In 1957, commune members in Ninghai initiated protests; 51 agricultural communes were disbanded and 42 communes were nearly disbanded (Codification Committee of Ninghai County 1993, 180). In Yueqing, 44 cooperative communes were disbanded and 4989 households withdrew from communes and began to again work for themselves. The government of Yueqing subsequently had to scale down large advanced communes (Codification Committee of Yueqing County 2000, 397).

In 1957, the practice of quitting communes was also common throughout Ruian and Pingyang (Codification Committee of Local History of Ruian City 2003, 302; Codification Committee of Pingyang County 1993, 187). Additionally, 5000 households quit their communes by 1956 in Xiaoshan, accounting for $4.5 \%$ of all members, and 114 advanced cooperative communes were disbanded, accounting for $12 \%$ of the total advanced communes. Many towns also experienced protests by thousands of people; more than 200 peasants petitioned the provincial party committee (CCP Committee of Xiaoshan County 1957).

In the course of establishing advanced agricultural cooperative communes in Zhejiang, the areas with higher rates of quitting communes turned out to be areas with a strong revolutionary tradition and where the Eastern Zhejiang Guerrilla and the Southern Zhejiang Guerrilla were based. ${ }^{12}$ We found in field interviews that grassroots cadres with guerrilla backgrounds did not directly encourage peasants to quit communes. Quitting communes were widespread in these areas because many grassroots cadres maintained a lukewarm attitude toward the agricultural collectivization movement and turned a blind eye when farmers did not comply. Therefore, it was difficult for the entire county or even one advanced commune to adopt a unified policy that would fit all members. The inconsistency of implementing collectivization policies generated a strong sense of injustice among peasants and was more likely to trigger mass protests.

\section{The campaign of "Learning from the Dazhai Model in Agriculture"}

In 1964, the campaign of "Learning from the Dazhai Model in Agriculture" was launched across the country and persisted until 1978. During the Cultural Revolution, the Dazhai experience was deliberately used to escalate political and class struggles. In rural areas, governments criticized "three privates and one contract (三自一包), four freedoms (四大自由), work points matter (工分挂帅), and material incentives (物质刺激).” Instead, they stressed the "three contributions and one unification" (三献一并): contributing private plots (自留地), food patches (饲料地), and private hills (自留山) to communes and merging agricultural teams to the higher level (并队升级). While some counties aggressively promoted the Dazhai Model and discouraged peasants from increasing agricultural production, other counties boycotted this campaign and protected local economic interests.

Almost all of the counties in the Wenzhou area were lukewarm about the Campaign of Learning from the Dazhai Model in Agriculture. At that time, the practices of 
“distributing in small production teams" (分小小队) and “distributing farmlands to households” (分田到户) were widespread in Wenzhou (Codification Committee of Wenzhou City 1998, 1419). For example, some villages in Yueqing attempted to upgrade and merge agricultural teams but peasants resisted this policy. As a result, production terms were nominally merged but in reality independent, and the production team remained the basic accounting unit (Codification Committee of Yueqing County 2000, 398). In Ruian, the policies of "scoring by political performance" (政治评分) and "three contributions and one unification" (三献一并) were implemented in only a few communes and were abolished in 1972 (Codification Committee of Local History of Ruian City 2003, 302).

Similar to Wenzhou, the "three-level ownership and team-based system" (三级所有,队 为基础) was generally maintained in the counties of Jinhua. Only a few areas followed the policy of political scoring and abolished private plots, which lasted only a short period (Codification Committee of Jinhua City 1992, 370). For example, Wuyi and Yiwu redistributed private plots, restored the workload scoring system, and changed the basic accounting unit from brigades to production teams in the early 1970s (Codification Committee of Wuyi County 1990, 179; Codification Committee of Yiwu County 1987, 103). Moreover, the cadres and masses of Xiaoshan also boycotted the two-level accounting system and other left-leaning policies and maintained a three-level accounting system (Codification Committee of Xiaoshan County 1987, 219).

However, in other areas of Zhejiang, local governments failed to resist the campaign of Learning from the Daizhai Model in Agriculture. In the Huzhou area, the local government embraced the political scoring of the Dazhai Model during the $\mathrm{CR}$, reduced the proportion of private plots, and pushed forward the upgrade of production teams. Some "leftist" policies of Deqing were even applauded by the Revolutionary Committee of Zhejiang province (Codification Committee of CCP Zhejiang Committee 2007, 11). It was not until December 1976 that brigades in Huzhou were restored to their original size, private plots were returned to commune members, and political scoring was canceled (Codification Committee of Huzhou City 1999, 529).

In the campaign of Learning from the Dazhai Model in Agriculture, the practices of two-level accounting and three contributions and one unification were in fact aimed at centralizing economic power in higher-level governments, thereby extracting more economic resources from the rural areas. In the areas dominated by guerrilla cadres, the governments were less likely to enact radical policies and extract economic surplus aggressively. In contrast, in the areas dominated by southbound cadres, the government officials had close ties to the higher-level governments and had strong incentive to extract economic resources.

\section{The commercial and industrial policies of local governments in Zhejiang province}

China's TVEs originated from commune and brigade enterprises during the agricultural collectivization period. However, in the economic adjustment after the Great Leap Forward, most commune and brigade enterprises were shut down. After the outbreak of the $\mathrm{CR}$, the production of state-owned factories was disrupted and undermined, leading to large-scale commodity shortages. At this point, the commune and brigade enterprises resurged. In August 1970, the State Council held a meeting about agriculture in northern China; at this meeting, Premier Zhou 
pushed forward agricultural mechanization. In September 1971, the State Council held a national conference on agricultural mechanization and decided to develop commune and brigade enterprises and promote rural industrialization. A large number of commune and brigade enterprises in Zhejiang then began to flourish. During the $\mathrm{CR}$, the average annual growth of the industrial output of commune and brigade enterprises was 15.8 \% (Codification Committee of CCP Zhejiang Committee 2007, 16). More importantly, rural industrialization paved the way for the development of the private economy. In fact, during the reform era, private enterprise in Zhejiang stemmed from "red hat" commune and brigade enterprises.

During the 1960s and 1970s, rural industry in the Ningbo area achieved rapid growth. For example, the party committee of Yin County decided to restore and develop commune and brigade industries as early as in 1964. After the promulgation of Mao Zedong's "May 7th Instruction"13 in 1966, all communes and brigade founded repair shops for agricultural machinery along with electromechanical irrigation and drainage pumping stations. Yin established 480 commune and brigade enterprises, accounting for $36 \%$ of its industrial output in 1966. By 1978, about $60 \%$ of industrial output was produced by commune and brigade enterprises (Codification Committee of Local History of Yin County 1996, 619-23).

As Table 1 shows the commune and brigade industries in Cixi, Yuyao, and Ninghai also blossomed during the CR. In 1978, the commune and brigade industry accounted for $51.98 \%$ of Cixi's total industrial output, $46.96 \%$ of Yuyao's and $43.15 \%$ of Ninghai's. The proportion of state-owned industry in the total value of industrial output declined from 80.28 to $43.96 \%$ in Cixi and 68.76 to $29.50 \%$ in Yuyao. The share of state-owned industry in Ninghai declined from 81.58 \% in 1965 to $39.04 \%$ in 1978 (Codification Committee of

Table 1 Change of ownership structure for industrial production at the county level

\begin{tabular}{|c|c|c|c|c|}
\hline District & County & $\begin{array}{l}\text { Share of SOEs in } \\
\text { total industrial } \\
\text { output, } 1966(\%)\end{array}$ & $\begin{array}{l}\text { Share of SOEs in } \\
\text { total industrial } \\
\text { output, } 1978(\%)\end{array}$ & $\begin{array}{l}\text { Share of collective commune } \\
\text { and brigade enterprises in total } \\
\text { industrial output, } 1978(\%)\end{array}$ \\
\hline \multirow[t]{4}{*}{ Ningbo } & Yin & NA & $<40$ & 60 \\
\hline & Cixi & 80.28 & 43.96 & 51.98 \\
\hline & Yuyao & 68.76 & 29.50 & 46.96 \\
\hline & Ninghai & 81.58 & 39.04 & 43.15 \\
\hline \multirow[t]{4}{*}{ Wenzhou } & Yueqing & 40.21 & 28.87 & 42.00 \\
\hline & Pingyang & NA & $<50$ & 41.07 \\
\hline & Yongjia & 56.52 & 16.78 & 42.54 \\
\hline & Ruian & 39.52 & 20.95 & 30.61 \\
\hline \multirow[t]{3}{*}{ Jiaxing } & Jiashan & 77.42 & 55.10 & 16.71 \\
\hline & Haining & 84.94 & 53.41 & 26.31 \\
\hline & Pinghu & NA & NA & 19.29 \\
\hline \multirow[t]{2}{*}{ Huzhou } & Deqing & 78.62 & $>50$ & 23.94 \\
\hline & Anji & 70.34 & 75.24 & 13.64 \\
\hline \multirow[t]{4}{*}{ Quzhou } & Quxian & 75.65 & 66.62 & 12.26 \\
\hline & Changshan & 73.00 & 72.80 & NA \\
\hline & Longyou & 83.61 & 72.36 & 13.87 \\
\hline & Kaihua & 84.95 & 79.31 & 7.63 \\
\hline
\end{tabular}

Data source: various county gazetteers 
Local History of Cixi City 1992, 381-85; Codification Committee of Ninghai County 1993, 350-51; Codification Committee of Local History of Yuyao City 1993, 307 and 311). The development of commune and brigade enterprises indicates that local governments were less able to extract resources from the rural areas and that the grassroots elites had more economic surplus to develop industries.

The development of rural industry in Wenzhou and Ningbo has a similar story. During the CR, commune and brigade enterprises grew rapidly in Yueqing except in some remote mountainous areas. In 1978, the industrial output of commune and brigade enterprises accounted for about $42.54 \%$ of the total industrial output; in 1979, the taxes contributed by commune and brigade enterprises accounted for $38.5 \%$ of the county's fiscal revenue. The proportion of the industrial output of state-owned enterprises declined from $56.52 \%$ in 1966 to $16.78 \%$ in 1978 (Codification Committee of Yueqing County 2000, 505-506, 530-31).

It should be noted that even in the counties with the same revolutionary tradition, the development of rural industries was extremely uneven. In the areas of Yueqing Plain, particularly in Liushi District and Hongqiao District, the commune and brigade industry started to develop rapidly in the 1970s. Local guerrillas were very influential in these two areas before 1949. In our interviews in Hongqiao and Liushi, we found that a large number of village cadres with guerrilla backgrounds set up various commune and brigade enterprises in the 1970s. Among them, many enterprises were nominally collective but in actual fact privately owned. The cadres in various levels of governments who were from the Yongyue guerrilla (even guerrilla cadres in the provincial-level government) provided economic and political support when these enterprises were founded. Since the development of enterprises brought tangible benefits to local people, the political power base of guerrilla cadres was further consolidated. ${ }^{14}$

Unlike in eastern and southern Zhejiang, the commune and brigade enterprises developed slowly in southwestern and northern Zhejiang where guerrilla forces were relatively weak before 1949. However, in terms of geographical conditions and economic foundations, northern Zhejiang was no worse than eastern Zhejiang and better than southern Zhejiang. In the Jiaxing area, the development of commune and brigade industries in Jiashan fluctuated during the CR. By 1978, the industrial output value of commune and brigade enterprises only accounted for $16.71 \%$ of total output (Codification Committee of Jiashan County 1995, 303, 310-11). Similarly, the commune and brigade industry of Haining stagnated, and the industrial output value of commune and brigade industry only accounted for $26.31 \%$ of total industrial output in 1978 (Codification Committee of Haining City 1995, 182-84). In Pinghu, the industrial output value by commune and brigade industries only accounted for $19.29 \%$ of total industrial output in 1977 (Codification Committee of Pinghu County 1992, 278).

The government of Quzhou in southwestern Zhejiang did not even reach a consensus that industry must play a leading role in local economy until the early 1980s (Codification Committee of Quzhou City 1994, 406). In Changshan, commune and brigade enterprises did not develop until 1977. State-owned industry accounted for $73.0 \%$ of total industrial output in 1966 and remained at 72.8 \% in 1978 (Codification Committee of Changshan County 1990, 232-33). In addition, the industrial output of commune and 
brigade enterprises in Kaihua, whose per capita industrial output in 1952 was ranked in the top ten of Zhejiang province, accounted for only $7.63 \%$ of total industrial output. ${ }^{15}$ Meanwhile, the share of state-owned industry in the total industrial output only declined slightly, from 84.95 \% in 1966 to 79.31 \% in 1978 (Codification Committee of Kaihua County 1988, 212-13). Because of the slow development of commune and brigade enterprises, Kaihua was ranked in the bottom 12 for per capita GDP in 1988, despite well-established industrial foundations after $1949 .^{16}$

With the rapid development of rural industries, many counties with the guerrilla tradition enacted policies that sheltered the development of markets during the 1960s and 1970s, resulting in "prohibiting public markets but acquiescing secret ones." 17 The unlicensed vendors in Wenzhou "did not decrease in number" although they were punished for being "capitalist forces." By May 1976, there were more than 11,000 unlicensed vendors (Codification Committee of Wenzhou City 1998, 2014). Self-organized markets were everywhere in Yongjia: the Lingku Market at the junction of Yongjia and Yueqing was the biggest black market in southern Zhejiang. The number of people trading in that market reached a maximum of about 10,000, yet it was not banned (Codification Committee of Local History of Yongjia County 2003, 656). In Ruian, there were several black markets for trading wood, vegetables, and farm animals (Codification Committee of Local History of Ruian City 2003, 358). Although markets in Pingyang were sometimes closed, they were never completely banned (Editorial Department of Market History of Zhejiang province 2000, 558, 603).

However, the local government in Quzhou implemented the "rather left than right" (宁左勿右) policy so that peasants who sold agricultural products were denounced as "taking the capitalist road." In addition, Quzhou also decisively banned underground factories, shops, and construction and transportation workshops (Editorial Department of Industry and Commerce Administration of Quzhou City 1995, 103). For example, during the CR, the government of Kaihua regarded the freedom of trading as one of the "four freedoms" and strictly prohibited trading in markets (Codification Committee of Kaihua County 1988, 279). In Jiangshan, the grain market was closed in 1968 and even a small volume of trading was criticized as "abandoning agriculture and speculating." Not surprisingly, underground factories and black shops were also banned in Jiangshan (Codification Committee of Jiangshan City 1990, 324).

The industrial and commercial markets in the rural areas of Zhejiang emerged and flourished during the CR. The development of markets not only benefited from the central government's reorientation in economic policy around 1970 but was also a political consequence of the CR changing the power configuration of local politics. In our field interviews in Wenzhou, we noticed that compared to southbound cadres, guerrilla cadres were better able to protect themselves due to mass support during the CR and were soon rehabilitated in the $1970 \mathrm{~s} .{ }^{18}$ Although the majority of the leading positions in county-level and prefecture-level governments of Zhejiang were still occupied by southbound cadres in the 1970s, their ability to exert political pressure on local guerrilla cadres gradually weakened. As a consequence, guerrilla cadres were able to promote their marketpreserving policies to a larger extent. Furthermore, it is worth noting that this mass support helped the guerrilla cadres survive during the CR. We found in 
interviews that the southbound cadres of Wenzhou had tried to mobilize peasants to denounce guerrilla cadres during the "Four Clean-ups" Movement (四清运动), but the peasants refused to cooperate with the working groups sent by the higher-level government and thus protected the guerrilla cadres.

As shown in Fig. 2, from the 1970s to the 1990s, most members of the provincial party standing committee were promoted from non-guerrilla counties. In other words, local cadres from guerrilla counties were not only marginalized by southbound cadres before the $\mathrm{CR}$ but also lacked promotion opportunities after the CR. Therefore, guerrilla cadres had the incentive to continue protecting the mass interests as well as upholding market-preserving policies.

\section{Methods}

The above historical studies show that there were significant differences in the enforcement of agricultural, industrial, and business policies between guerrilla counties and non-guerrilla counties. More importantly, we argue that these differences also had a significant impact on the development of the private economy and long-term economic performance. This section uses county-level data to test the effect of guerrilla legacies on economic development. The dependent variables constitute the indicators measuring economic growth and the development of the private economy. The main independent variable is the strength of local guerrillas prior to 1949. We also control a set of variables, including geographic factors and initial economic conditions.

\section{Model specification and data source}

In order to measure the disparity of economic development at the county level, we use the following four dependent variables: the average growth rate of per capita industrial output from 1978 to 1998 and from 1952 to 1998; per capita non-state-owned industrial output in 1998; and per capita non-state-owned industrial output and non-foreign-invested industrial output in $1998 .{ }^{19}$ We take the logarithm of the last two variables. ${ }^{20}$ The data on per capita industrial output in 1952, 1978, and 1998 are mainly drawn from Compiled Statistical Material of New Zhejiang in 50 Years (Statistical Bureau of Zhejiang province 2000). The industrial outputs in 1952 and in 1978 are deflated to the price in 1998. The data of all counties in the Ningbo area is drawn from county gazetteers.

We use a dummy variable to measure the strength of a local guerrilla force before 1949. If a county had established a formal guerrilla army during the Liberation War, then the guerrilla of that county was viewed as "strong." On the contrary, if a county had not established any guerrillas during the Liberation War, then the guerrilla of that county was viewed as "weak." However, as the Liberation War unfolded, the KMT was less able to control counties in Zhejiang such that the guerrilla forces expanded to other counties. Through using the Historical Material of Organization of CCP in Zhejiang province (Organization Department of CCP Zhejiang 1994) and county gazetteers, we define the counties with strong guerrilla forces as those with established guerrillas prior to May 1948 (1 year before the liberation of Zhejiang's capital city, Hangzhou); otherwise, the counties were regarded as having weak or no guerrillas. If the local guerrilla of a county before May 1948 was strong, we coded it as "1"; otherwise, it was coded 
as "0." We expect this dummy variable to have a positive impact on economic development. $^{21}$

Liu (1992) argues that being liberated by armies with different political backgrounds would have different effects on economic development. As mentioned previously, the southbound cadres from Shandong province played an important role in the various levels of governments in Zhejiang. Therefore, one can wonder if southbound cadres were better able to control the local government in the regions liberated by the field army from the Shandong base area. Likewise, we wanted to know if cadres with guerrilla backgrounds were more likely to implement economic policies that protected the masses. To assess these hypotheses, we constructed two dummy variables based on the book The Liberation of Zhejiang (Party History Research and Data Collection Committee of CCP Zhejiang province, Political Department of Zhejiang Military Command of PLA 1989). One variable measures whether a county was liberated by the field army from the Shandong revolutionary base area. That is, if a county was liberated by the 22nd, 26th, 27th, 28th, 31st, $33 \mathrm{rd}$, or 35 th army of the Third Field Army, the variable was coded as " 1 "; otherwise, it was coded as "0." This variable is intended to test whether the "liberation effect" would strengthen the influence of southbound cadres in local governments. The other dummy variable measures whether a county was liberated by a guerrilla, i.e., if a county was liberated by a guerrilla, it was coded as "1," otherwise it was coded as "0." 22

Control variables in our model specification include the initial economic condition and geographic variables. The initial economic condition was measured by three variables: the per capita industrial output in 1952, population size in 1952, and per capita arable land in 1952. In the model of industrial output growth from 1978 to 1998, we also control the per capita industrial output in 1978. Geographic variables consist of the average altitude, the share of flat ground whose slope gradient is less than $15^{\circ}$ in total county area ${ }^{23}$, the distance to Shanghai, as well as the length of coastline (equal to zero for an inland county). The last two variables reflect a county's location advantage via its access to a superbusiness hub (Shanghai) or a port. To control the effect of human capital on long-term economic growth, we draw on Zhu and Xie (1980) work and use the total number of chinshihs (进士) in each county during the Ming Dynasty and Qing Dynasty as a proxy for the historical education tradition. Moreover, we take the logarithm of the following four control variables: average altitude, length of coastline, number of chinshihs, and distance to Shanghai. Table 2 provides the descriptive statistics of the data.

\section{Results and discussions}

As shown in model 1 of Table 3, the independent variable that measures the strength of guerrilla force is significant at the $5 \%$ level and has a positive effect on the average growth rate of per capita industrial output from 1978 to 1998. Holding other factors as constant, the guerrilla counties had a $2.4 \%$ higher growth rate of per capita industrial output from 1978 to 1998 . The estimated coefficient of the per capita industrial output in 1978 is negative and significant at the $1 \%$ level, indicating a trend of conditional convergence among all counties in Zhejiang in the post-1978 period. In other words, the initial economic condition was not a determining factor of economic growth in the 
Table 2 Descriptive statistics

\begin{tabular}{llllll}
\hline Variables & OBS & Mean & SD & Min & Max \\
\hline $\begin{array}{l}\text { Annual growth rate of per capita industrial output value from } \\
\text { 1978-1998 (\%) }\end{array}$ & 58 & 12.18 & 2.30 & 8.13 & 17.08 \\
Annual growth rate of per capita industrial output value from & 58 & 12.09 & 2.22 & 5.41 & 17.96 \\
1952-1998 (\%) & & & & & \\
Per capita non-state-owned industrial output value in 1998 & 58 & 19628.17 & 13961.54 & 1184.39 & 48343.86 \\
Per capita non-state-owned and non-foreign-invested industrial & 58 & 18495.25 & 13062.47 & 1168.37 & 45558.35 \\
output value in 1998 & & & & & \\
Strength of local guerrillas (1 = strong, 0 = weak) & 58 & 0.63 & 0.48 & 0 & 1 \\
Liberated by guerrilla (1 =yes, 0=no) & 58 & 0.29 & 0.46 & 0 & 1 \\
Liberated by field armies from Shandong (1=yes, 0=no) & 58 & 0.47 & 0.50 & 0 & 1 \\
Population in 1952 (10,000) & 58 & 28.56 & 16.15 & 4.06 & 79.22 \\
Per capita arable land in 1952 (hectare/10.000) & 58 & 982.58 & 309.87 & 148.00 & 1705.00 \\
Per capita industrial output value in 1952 (Yuan, in 1998 price) & 58 & 98.70 & 77.48 & 15.38 & 458.22 \\
Per capita industrial output value in 1978 (Yuan,in 1998 price) & 58 & 611.61 & 316.54 & 49.59 & 1507.66 \\
Number of chinshihs in Ming and Qing Dynasties & 58 & 70.97 & 108.63 & 0 & 640 \\
Average altitude (m) & 58 & 278.87 & 209.17 & 3.00 & 877.00 \\
Share of flat ground in total county area (\%) & 58 & 21.90 & 19.15 & 0.00 & 91.67 \\
Length of coastline (km) & 58 & 40.25 & 88.32 & 0 & 494.92 \\
Distance to Shanghai (km) & 58 & 262.03 & 108.00 & 51.15 & 456.75 \\
\hline
\end{tabular}

reform era. For instance, while the initial economic condition of Southern Zhejiang was not promising at the beginning, the counties in this area were able to catch up to the relatively developed counties. In model 2 , the dependent variable is the growth rate of per capita industrial output from 1952 to 1998. Our independent variable, the strength of the guerrilla force, is positively significant at the $1 \%$ level. Holding other factors as constant, the guerrilla counties experienced a $1.4 \%$ higher growth rate of per capita industrial output from 1952 to 1998. This indicates that the guerrilla counties exhibited better long-run economic performance. In both models 3 and 4, our independent variable remains significant at the $1 \%$ level. It is worth mentioning that the coefficient of the number of chinshihs is statistically insignificant. Since the initial level of industrial development and the long-term economic performance are negatively correlated and the number of chinshihs has little bearing on the economic outcomes, we can conclude that the commercial and cultural tradition of a county had little impact on the economic performance of the post-1949 period.

In Table 4, we examine the effect of the Liberation War. We added two dummy variables as independent variables: one is "liberated by field armies from Shandong province or not" and the other is "liberated by local guerrillas or not." All the other dependent variables and control variables are the same as the previous models. As shown in Table 4, these two dummy variables are not significant in all four models, indicating that the source of liberation forces is less important than the strength of local guerrillas in shaping the political power configuration and driving economic development. In Table 5, we interacted "strength of local guerrillas" and "source of liberation armies" and obtained two additional dummy variables, namely "counties with strong guerrillas and independently liberated by guerrillas" and "counties with weak guerrillas and liberated by the field armies from Shandong." The two newly constructed variables 
Table 3 Results of OLS regression I

\begin{tabular}{|c|c|c|c|c|}
\hline & Model 1 & Model 2 & Model 3 & Model 4 \\
\hline & $\begin{array}{l}\text { Annual growth } \\
\text { rate of per capita } \\
\text { industrial output } \\
\text { value from } \\
\text { 1978-1998 (\%) }\end{array}$ & $\begin{array}{l}\text { Annual growth } \\
\text { rate of per capita } \\
\text { industrial output } \\
\text { value from } \\
\text { 1952-1998 (\%) }\end{array}$ & $\begin{array}{l}\text { Ln (per capita } \\
\text { non-state-owned } \\
\text { industrial output } \\
\text { value in 1998) } \\
\text { (yuan) }\end{array}$ & $\begin{array}{l}\text { Ln (per capita } \\
\text { non-state- owned } \\
\text { and non-foreign- } \\
\text { invested industrial } \\
\text { output value in } \\
\text { 1998) (yuan) }\end{array}$ \\
\hline \multicolumn{5}{|l|}{ Independent variable } \\
\hline Strength of guerrillas & $2.400^{* *}$ & $1.395^{* * *}$ & $0.551^{* * *}$ & $0.559^{* * *}$ \\
\hline$(1=$ strong, 0 = weak $)$ & $(2.11)$ & $(3.15)$ & $(2.95)$ & $(2.95)$ \\
\hline \multicolumn{5}{|l|}{ Control variables } \\
\hline \multicolumn{5}{|l|}{ Initial economic conditions } \\
\hline \multirow[t]{2}{*}{$\begin{array}{l}\text { Ln (per capita industrial } \\
\text { output value in 1978) }\end{array}$} & $-2.476^{* *}$ & & & \\
\hline & $(-2.46)$ & & & \\
\hline \multirow{2}{*}{$\begin{array}{l}\text { Ln (per capita industrial } \\
\text { output value in 1952) }\end{array}$} & & $-2.742^{* * *}$ & -0.136 & -0.136 \\
\hline & & $(-5.41)$ & $(-0.64)$ & $(-0.64)$ \\
\hline \multirow[t]{2}{*}{ Ln (population in 1952) } & $3.063^{* * *}$ & $1.034^{* *}$ & $0.479^{* * *}$ & $0.479^{* * *}$ \\
\hline & $(3.15)$ & $(2.48)$ & $(2.77)$ & $(2.73)$ \\
\hline \multirow[t]{2}{*}{ Ln (number of chinshihs) } & 0.037 & 0.128 & 0.063 & 0.063 \\
\hline & $(0.05)$ & $(0.40)$ & $(0.45)$ & $(0.45)$ \\
\hline \multirow{2}{*}{$\begin{array}{l}\text { Ln (per capita arable land } \\
\text { in 1952) }\end{array}$} & 1.853 & $1.651^{* *}$ & $0.638^{* *}$ & $0.659^{* *}$ \\
\hline & $(1.22)$ & $(2.41)$ & $(2.18)$ & $(2.23)$ \\
\hline \multicolumn{5}{|l|}{ Geographic Factors } \\
\hline \multirow[t]{2}{*}{ Ln (length of coastline) } & 0.214 & 0.114 & 0.0514 & 0.0495 \\
\hline & $(0.82)$ & $(0.94)$ & $(1.01)$ & $(0.95)$ \\
\hline \multirow[t]{2}{*}{ Ln (average altitude) } & -0.600 & -0.499 & -0.197 & -0.202 \\
\hline & $(-0.42)$ & $(-0.89)$ & $(-0.83)$ & $(-0.84)$ \\
\hline \multirow{2}{*}{$\begin{array}{l}\text { Share of flat ground in } \\
\text { total county area (\%) }\end{array}$} & 0.006 & -0.002 & 0.000 & 0.000 \\
\hline & $(0.09)$ & $(-0.09)$ & $(-0.01)$ & $(-0.01)$ \\
\hline \multirow[t]{2}{*}{ Ln (distance to Shanghai) } & -1.484 & -1.268 & -0.501 & -0.415 \\
\hline & $(-0.59)$ & $(-1.20)$ & $(-1.09)$ & $(-0.89)$ \\
\hline F statistics & 10.26 & 9.31 & 14.57 & 13.00 \\
\hline$R^{2}$ & 0.48 & 0.59 & 0.60 & 0.57 \\
\hline OBS & 58 & 58 & 58 & 58 \\
\hline
\end{tabular}

Robust t-statistics in parentheses

***Significant at $1 \%$; * Significant at $5 \%$; ${ }^{*}$ Significant at $10 \%$

are insignificant in all the regressions, implying that being liberated by specific troops was not a determinant of long-run economic growth.

In order to test the robustness of our analysis, we use two alternative measures of the strength of guerrillas. One is whether a local guerrilla persisted $(1=$ yes, $0=$ not $)$ during the Sino-Japanese War and the Liberation War (1944-1948). Not surprisingly, the number of guerrilla counties decreased when we use this demanding measure. The results reported in Table 6 show that the alternative measure of the strength of guerrillas is significant across all four specifications. The other strategy is to classify local guerrillas into main forces and 
Table 4 Results of OLS regression ॥

\begin{tabular}{|c|c|c|c|c|}
\hline & Model 1 & Model 2 & Model 3 & Model 4 \\
\hline & $\begin{array}{l}\text { Annual growth } \\
\text { rate of per capita } \\
\text { industrial output } \\
\text { value from } \\
\text { 1978-1998 (\%) }\end{array}$ & $\begin{array}{l}\text { Annual growth } \\
\text { rate of per capita } \\
\text { industrial output } \\
\text { value from } \\
\text { 1952-1998 (\%) }\end{array}$ & $\begin{array}{l}\text { Ln (per Capita } \\
\text { non-state- owned } \\
\text { industrial output } \\
\text { value in 1998) } \\
\text { (yuan) }\end{array}$ & $\begin{array}{l}\text { Ln (per Capita non- } \\
\text { state-owned and } \\
\text { non-foreign-invested } \\
\text { industrial output } \\
\text { value in 1998) (yuan) }\end{array}$ \\
\hline Independent variables & $2.376^{* *}$ & $1.445^{* * *}$ & $0.573^{* * *}$ & $0.575^{* * *}$ \\
\hline $\begin{array}{l}\text { Strength of guerrillas } \\
(1=\text { strong, } 0=\text { weak })\end{array}$ & (2.08) & $(3.46)$ & $(3.25)$ & $(3.20)$ \\
\hline Liberated by guerrillas & 0.229 & -0.302 & -0.127 & -0.100 \\
\hline$(1=$ yes, $0=$ no $)$ & $(0.18)$ & $(-0.52)$ & $(-0.52)$ & $(-0.40)$ \\
\hline Liberated by field armies & -0.365 & -0.091 & -0.049 & -0.033 \\
\hline$(1=$ yes, $0=$ no $)$ & $(-0.33)$ & $(-0.18)$ & $(-0.23)$ & $(-0.15)$ \\
\hline \multicolumn{5}{|l|}{ Control variables } \\
\hline \multicolumn{5}{|l|}{ Initial economic conditions } \\
\hline \multirow[t]{2}{*}{$\begin{array}{l}\text { Ln (per capita industrial } \\
\text { output value in 1978) }\end{array}$} & $-2.379^{* *}$ & & & \\
\hline & $(-2.33)$ & & & \\
\hline \multirow{2}{*}{$\begin{array}{l}\text { Ln (per capita industrial } \\
\text { output value in 1952) }\end{array}$} & & $-2.738^{* * *}$ & -0.134 & -0.134 \\
\hline & & $(-5.28)$ & $(-0.61)$ & $(-0.62)$ \\
\hline \multirow[t]{2}{*}{ Ln (population in 1952) } & $2.789^{* *}$ & $1.121^{*}$ & $0.510^{* *}$ & $0.507^{* *}$ \\
\hline & $(2.08)$ & $(1.95)$ & $(2.10)$ & $(2.05)$ \\
\hline \multirow[t]{2}{*}{ Ln (number of chinshihs) } & 0.072 & 0.103 & 0.053 & 0.055 \\
\hline & $(0.10)$ & $(0.31)$ & $(0.37)$ & $(0.38)$ \\
\hline \multirow{2}{*}{$\begin{array}{l}\text { Ln (per capita arable land } \\
\text { in 1952) }\end{array}$} & 1.803 & $1.622^{* *}$ & $0.625^{* *}$ & $0.649^{* *}$ \\
\hline & $(1.18)$ & $(2.30)$ & $(2.07)$ & $(2.12)$ \\
\hline \multicolumn{5}{|l|}{ Geographic Factors } \\
\hline \multirow[t]{2}{*}{ Ln (length of coastline) } & 0.220 & 0.105 & 0.048 & 0.047 \\
\hline & $(0.81)$ & $(0.85)$ & $(0.92)$ & $(0.88)$ \\
\hline \multirow[t]{2}{*}{ Ln (average altitude) } & -0.412 & -0.542 & -0.212 & -0.215 \\
\hline & $(-0.30)$ & $(-0.93)$ & $(-0.86)$ & $(-0.86)$ \\
\hline \multirow{2}{*}{$\begin{array}{l}\text { Share of flat ground in } \\
\text { total county area (\%) }\end{array}$} & 0.019 & -0.005 & 0.000 & 0.000 \\
\hline & $(0.26)$ & $(-0.15)$ & $(-0.06)$ & $(-0.06)$ \\
\hline \multirow[t]{2}{*}{ Ln (distance to Shanghai) } & -1.462 & -1.195 & -0.469 & -0.390 \\
\hline & $(-0.59)$ & $(-1.12)$ & $(-1.01)$ & $(-0.83)$ \\
\hline F statistics & 8.70 & 8.28 & 14.41 & 12.41 \\
\hline$R^{2}$ & 0.48 & 0.59 & 0.60 & 0.58 \\
\hline OBS & 58 & 58 & 58 & 58 \\
\hline
\end{tabular}

Robust t-statistics in parentheses

***Significant at $1 \%$; **Significant at $5 \%$; *Significant at $10 \%$

ordinary forces. We construct two variables of "whether a county established a main-force guerrilla ( 1 =yes, 0 = otherwise)" and "whether a county established an ordinary guerrilla ( 1 =yes, $0=$ otherwise)." Here, the main-force guerrillas in Eastern Zhejiang were the First Branch of Jinxiao Guerrilla (金萧游击第一支队) and the People's Patriotic and Self-defense Team of Siming Mountain (四明山人 
Table 5 Results of OLS regression III

\begin{tabular}{|c|c|c|c|c|}
\hline & Model 1 & Model 2 & Model 3 & Model 4 \\
\hline & $\begin{array}{l}\text { Annual growth } \\
\text { rate of per capita } \\
\text { industrial output } \\
\text { value from } \\
\text { 1978-1998 (\%) }\end{array}$ & $\begin{array}{l}\text { Annual growth } \\
\text { rate of per capita } \\
\text { industrial output } \\
\text { value from } \\
\text { 1952--1998 (\%) }\end{array}$ & $\begin{array}{l}\text { Ln (per capita } \\
\text { non-state-owned } \\
\text { industrial output } \\
\text { value in 1998) } \\
\text { (yuan) }\end{array}$ & $\begin{array}{l}\text { Ln (per capita non- } \\
\text { state-owned and } \\
\text { non-foreign-invested } \\
\text { industrial toutput } \\
\text { value in 1998) (yuan) }\end{array}$ \\
\hline \multicolumn{5}{|l|}{ Independent variables } \\
\hline $\begin{array}{l}\text { Strong guerrillas and } \\
\text { liberated by guerrillas }\end{array}$ & 1.360 & 0.240 & 0.105 & 0.121 \\
\hline$(1=$ yes, $0=$ no $)$ & $(0.91)$ & $(0.33)$ & $(0.33)$ & $(0.38)$ \\
\hline $\begin{array}{l}\text { Weak guerrillas and } \\
\text { liberated by field armies }\end{array}$ & -1.074 & -0.470 & -0.165 & -0.160 \\
\hline$(1=$ yes, $0=$ no $)$ & $(-0.96)$ & $(-0.91)$ & $(-0.79)$ & $(-0.74)$ \\
\hline \multicolumn{5}{|l|}{ Control variables } \\
\hline \multicolumn{5}{|l|}{ Initial economic conditions } \\
\hline \multirow[t]{2}{*}{$\begin{array}{l}\text { Ln (per capita industrial } \\
\text { output value in 1978) }\end{array}$} & $-1.935^{* *}$ & & & \\
\hline & $(-2.17)$ & & & \\
\hline \multirow{2}{*}{$\begin{array}{l}\text { Ln (per capita industrial } \\
\text { output value in 1952) }\end{array}$} & & $-2.640^{* * *}$ & -0.096 & -0.096 \\
\hline & & $(-4.53)$ & $(-0.40)$ & $(-0.40)$ \\
\hline \multirow[t]{2}{*}{ Ln (population in 1952) } & $2.895^{* *}$ & $1.204^{* *}$ & $0.546^{* *}$ & $0.542^{* *}$ \\
\hline & $(2.23)$ & $(2.07)$ & $(2.26)$ & $(2.20)$ \\
\hline \multirow{2}{*}{$\begin{array}{l}\text { Ln (number of chinshihs in } \\
\text { Ming and Qing Dynasties) }\end{array}$} & 0.0124 & 0.054 & 0.034 & 0.035 \\
\hline & $(0.02)$ & $(0.16)$ & $(0.23)$ & $(0.24)$ \\
\hline \multirow{2}{*}{$\begin{array}{l}\text { Ln (per capita arable land } \\
\text { in 1952) }\end{array}$} & 0.873 & 0.960 & 0.358 & 0.373 \\
\hline & $(0.57)$ & $(1.18)$ & $(1.06)$ & $(1.10)$ \\
\hline \multicolumn{5}{|l|}{ Geographic factors } \\
\hline \multirow[t]{2}{*}{ Ln (length of coastline) } & 0.291 & 0.163 & 0.0716 & 0.0703 \\
\hline & $(1.08)$ & $(1.37)$ & $(1.43)$ & $(1.38)$ \\
\hline \multirow[t]{2}{*}{ Ln (average altitude) } & 0.538 & 0.0672 & 0.0321 & 0.0356 \\
\hline & $(0.41)$ & $(0.11)$ & $(0.12)$ & $(0.13)$ \\
\hline \multirow{2}{*}{$\begin{array}{l}\text { Share of flat ground in } \\
\text { total county area (\%) }\end{array}$} & 0.043 & 0.010 & 0.005 & 0.005 \\
\hline & $(0.64)$ & $(0.33)$ & $(0.39)$ & $(0.41)$ \\
\hline \multirow[t]{2}{*}{ Ln (distance to Shanghai) } & -2.335 & -1.887 & -0.759 & -0.684 \\
\hline & $(-0.90)$ & $(-1.59)$ & $(-1.49)$ & $(-1.32)$ \\
\hline F statistics & 9.96 & 7.43 & 13.76 & 11.91 \\
\hline$R^{2}$ & 0.46 & 0.54 & 0.56 & 0.53 \\
\hline OBS & 58 & 58 & 58 & 58 \\
\hline
\end{tabular}

Robust t-statistics in parentheses

***Significant at $1 \%$; **Significant at $5 \%$; Significant at $10 \%$

民爱国自卫总队). The main-force guerrillas in Southern Zhejiang were the Kuocang Branch (括苍支队) and the Third Team of Self-assist and Anti-violence Troop of Young Men (浙江壮丁抗暴自救军第三总队). The counties that were influenced by these four main-force guerrillas were viewed as "main-force guerrilla counties", and all other counties were classified as "ordinary guerrilla counties." 
Table 6 Robustness check I

\begin{tabular}{|c|c|c|c|c|}
\hline & Model 1 & Model 2 & Model 3 & Model 4 \\
\hline & $\begin{array}{l}\text { Annual growth } \\
\text { rate of per capita } \\
\text { industrial output } \\
\text { value from } \\
\text { 1978-1998 (\%) }\end{array}$ & $\begin{array}{l}\text { Annual growth } \\
\text { rate of per capita } \\
\text { industrial output } \\
\text { value from } \\
\text { 1952-1998 (\%) }\end{array}$ & $\begin{array}{l}\text { Ln (per capita } \\
\text { non-state-owned } \\
\text { industrial output } \\
\text { value in 1998) } \\
\text { (yuan) }\end{array}$ & $\begin{array}{l}\text { Ln (per capita non- } \\
\text { state-owned and } \\
\text { non-foreign-invested } \\
\text { industrial output } \\
\text { value in 1998) (yuan) }\end{array}$ \\
\hline \multicolumn{5}{|l|}{ Independent variables } \\
\hline \multicolumn{5}{|l|}{ Regression 1} \\
\hline Strength of guerrillas & $2.434^{* *}$ & $1.396^{* * *}$ & $0.598^{* * *}$ & $0.617^{* * *}$ \\
\hline$(1$ = strong, 0 = weak $)$ & $(2.11)$ & $(3.20)$ & $(3.29)$ & $(3.38)$ \\
\hline \multicolumn{5}{|l|}{ Regression 2} \\
\hline \multicolumn{5}{|l|}{ Strength of guerrillas } \\
\hline \multirow[t]{2}{*}{$(1=$ strong, $0=$ weak $)$} & $2.437^{* *}$ & $1.456^{* * *}$ & $0.625^{* * *}$ & $0.640^{* * *}$ \\
\hline & $(2.03)$ & $(3.30)$ & $(3.41)$ & $(3.46)$ \\
\hline \multicolumn{5}{|l|}{ Liberated by guerrillas } \\
\hline \multirow[t]{2}{*}{$(1=$ yes, $0=$ no $)$} & 0.109 & -0.359 & -0.160 & -0.136 \\
\hline & $(0.09)$ & $(-0.65)$ & $(-0.69)$ & $(-0.57)$ \\
\hline Liberated by field armies & -0.425 & -0.122 & -0.0685 & -0.0539 \\
\hline$(1=$ yes, $0=$ no $)$ & $(-0.40)$ & $(-0.25)$ & $(-0.33)$ & $(-0.25)$ \\
\hline \multicolumn{5}{|l|}{ Regression 3} \\
\hline $\begin{array}{l}\text { Strong guerrillas and } \\
\text { liberated by guerrillas }\end{array}$ & 1.354 & 0.341 & 0.147 & 0.161 \\
\hline$(1=$ yes, $0=$ no $)$ & $(0.92)$ & $(0.48)$ & $(0.48)$ & $(0.52)$ \\
\hline $\begin{array}{l}\text { Weak guerrillas and } \\
\text { liberated by field armies }\end{array}$ & -1.356 & -0.464 & -0.217 & -0.216 \\
\hline$(1=$ yes, $0=$ no $)$ & $(-1.24)$ & $(-0.91)$ & $(-0.99)$ & $(-0.97)$ \\
\hline
\end{tabular}

All regressions in Tables 6 and 7 have the same control variables as in Table 1. To save space, we do not report the estimation results of control variables, which are similar to the results in Table 1

The results in Table 7 show that our baseline findings remain robust and the magnitude of estimated coefficients of "main forces of guerrillas" is larger than that of "ordinary forces of guerrillas."

\section{Conclusions}

This paper has examined the historical legacy of the Chinese revolution and explained the variation in economic policies and growth performance across counties in Zhejiang province in the post-1949 era. We have shown that when there was no credible commitment to power sharing among the ruling elite, the marginalized political elites had the incentive to seek support from grassroots elites and the masses to ensure their own political survival. Under China's authoritarian regime, when the dominant group of elites monopolizes political resources, their rivals have little choice but to provide economic benefits to local constituents in return for their political support. This explains why, even in a single-party regime like China, there were still sufficient local initiatives for protecting the private economy in both the Maoist and reform eras when the political and economic environments were not ideal for capitalist economic sectors. The logic on the informal power configuration of local politics derived from Zhejiang can also be applied to other provinces, including Guangdong, Sichuan, and Shandong, where intraelite conflicts created opportunities for economic prosperity. 
Table 7 Robustness check II

\begin{tabular}{|c|c|c|c|c|}
\hline & Model 1 & Model 2 & Model 3 & Model 4 \\
\hline & $\begin{array}{l}\text { Annual growth } \\
\text { rate of per capita } \\
\text { industrial output } \\
\text { value from } \\
1978-1998 \text { (\%) }\end{array}$ & $\begin{array}{l}\text { Annual growth } \\
\text { rate of per capita } \\
\text { industrial output } \\
\text { value from } \\
\text { 1952-1998 (\%) }\end{array}$ & $\begin{array}{l}\text { Ln (per capita } \\
\text { non-state-owned } \\
\text { industrial output } \\
\text { value in 1998) } \\
\text { (yuan) }\end{array}$ & $\begin{array}{l}\text { Ln (per capita non- } \\
\text { state-owned and } \\
\text { non-foreign-invested } \\
\text { industrial output } \\
\text { value in 1998) (yuan) }\end{array}$ \\
\hline \multicolumn{5}{|l|}{ Independent variables } \\
\hline \multicolumn{5}{|l|}{ Regression 1} \\
\hline Main forces of guerrillas & $3.379^{* *}$ & $1.872^{* * *}$ & $0.763^{* * *}$ & $0.768^{* * *}$ \\
\hline$(1=$ yes, $0=$ no $)$ & $(2.62)$ & $(3.52)$ & $(3.43)$ & $(3.36)$ \\
\hline Ordinary forces of guerrillas & 1.828 & $1.103^{* *}$ & $0.421^{*}$ & $0.430^{* *}$ \\
\hline$(1=$ yes, $0=$ no $)$ & $(1.47)$ & $(2.20)$ & $(1.99)$ & $(2.02)$ \\
\hline \multicolumn{5}{|l|}{ Regression 2} \\
\hline Main forces of guerrillas & $3.348^{* *}$ & $1.937^{* * *}$ & $0.791^{* * *}$ & $0.791^{* * *}$ \\
\hline$(1=$ yes, $0=$ no $)$ & $(2.60)$ & $(3.65)$ & $(3.55)$ & $(3.43)$ \\
\hline Ordinary forces of guerrillas & 1.837 & $1.147^{* *}$ & $0.441^{* *}$ & $0.445^{* *}$ \\
\hline$(1=$ yes, $0=$ no $)$ & $(1.45)$ & $(2.39)$ & $(2.18)$ & $(2.17)$ \\
\hline Liberated by guerrillas & 0.117 & -0.343 & -0.145 & -0.118 \\
\hline$(1=$ yes, $0=$ no $)$ & $(0.09)$ & $(-0.58)$ & $(-0.58)$ & $(-0.46)$ \\
\hline Liberated by field armies & -0.296 & -0.0568 & -0.0344 & -0.0182 \\
\hline$(1=$ yes, $0=$ no $)$ & $(-0.26)$ & $(-0.11)$ & $(-0.16)$ & $(-0.08)$ \\
\hline \multicolumn{5}{|l|}{ Regression 9} \\
\hline $\begin{array}{l}\text { Main forces of guerrillas } \\
\text { and liberated by guerrillas }\end{array}$ & $3.031^{* *}$ & 1.037 & 0.438 & 0.463 \\
\hline$(1=$ yes, $0=$ no $)$ & $(2.07)$ & $(1.53)$ & $(1.53)$ & $(1.58)$ \\
\hline $\begin{array}{l}\text { Ordinary forces of guerrillas } \\
\text { and liberated by guerrillas }\end{array}$ & 0.124 & -0.327 & -0.133 & -0.123 \\
\hline$(1=$ yes, $0=$ no $)$ & $(0.07)$ & $(-0.35)$ & $(-0.34)$ & $(-0.31)$ \\
\hline $\begin{array}{l}\text { Weak guerrillas and } \\
\text { liberated by field armies }\end{array}$ & -1.151 & -0.516 & -0.184 & -0.180 \\
\hline$(1=$ yes, $0=$ no $)$ & $(-1.03)$ & $(-1.01)$ & $(-0.89)$ & $(-0.85)$ \\
\hline
\end{tabular}

The informal power configuration not only has a profound impact on economic development policies but also influences the development of various social forces and the formation of social capital at the local level. Our interviews in Wenzhou and other regions of Zhejiang show that local governments of guerilla counties began to take a tolerant attitude toward the emergence of various industrial and commercial associations, cultural societies, and clan and religious activities in the 1980s. By providing negotiation channels and communication platforms between political elites and social groups, various intermediate associations played an increasingly important role in local public affairs, such as constructing public projects, reducing political conflict, and improving social integration (Tsai 2007; Tao and Liu 2013; Hurst et al. 2014).

Of course, the reality may be more complex than the story recounted in this article, but we believe we have developed a framework to analyze the incentives and strategies of political elites for making political and economic decisions and understanding the regional disparity in growth performance and state-society relationships in authoritarian countries. 


\section{Endnotes}

${ }^{1}$ For a more comprehensive literature review see Qiu and $\mathrm{Xu}$ (2004).

${ }^{2}$ For instance, Shi et al. (2004a) argues that Zhejiang Province had poor natural endowments but a better commercial tradition, allowing the government to have a relatively tolerant attitude toward the private economy. However, such hypotheses have not been tested empirically.

${ }^{3}$ Kung and Lin (2003) find that the locales with established revolutionary bases had lower death rates during the Great Famine (1958-1961) because the relationship between grassroots cadres and the masses was close. The local governments in these places were less likely to excessively extract resources from the locals.

${ }^{4}$ For a discussion on informal political networks among political elites, see Shih (2007). In general, if the distribution of political power among elites is completely institutionalized, the political system will then distribute political power based on certain stable and objective indicators (like a performance-based evaluation system or the number of votes). In reality, however, we need to take into account the following circumstances: (a) the principle of distributing political power is often formulated by a small group of elites based on their own interests instead of the public interest; (b) power distribution is not institutionalized due to the absence of rules that can guarantee the institutionalized distribution of power, leading to frequent conflicts among political elites; (c) power conflicts among elites reinforce the uncertainty of power distribution rules, which allows political factions to play a critical role.

${ }^{5}$ Note that the meaning of the concept "political survival" is broader than that of political promotion. In reality, an official will still strive to maintain or maximize his existing power even if he/she has little opportunity of getting promoted.

${ }^{6}$ For this reason many Chinese regions experienced serious problems in economic growth. Although GDP and fiscal revenues increased substantially in some areas, the conflicts between cadres and the masses also escalated.

${ }^{7}$ On December 25, 1948, the East China Bureau of the CCP issued orders "on implementing the Central Committee of CCP's resolution for preparing 53,000 cadres" and pointed out that due to the current lack of cadres in central China, Shandong Province should take on the responsibility of preparing 15,000 cadres (Archival Bureau of Shandong Province 2005).

${ }^{8}$ Immediately following the liberation, the majority of official positions were occupied by local cadres with revolutionary experience in guerrilla counties. Since the southbound cadres took over the power of all counties, the situation had reversed. Whether in guerrilla counties or not, the party secretaries and the county heads were usually southbound cadres and local cadres serving in section-level (科级) positions or below. Nonetheless, in guerrilla counties the local cadres seemed more powerful. Between 1950 and 1966, local cadres filled $32 \%$ of county-level or vice-county-level positions in guerrilla counties, whereas only $14 \%$ of similar positions were filled by native cadres in no guerrilla counties.

${ }^{9}$ The positions do not include county party secretary and county head.

${ }^{10}$ Here, we define "guerrilla counties" as counties that had established guerrillas before May 1948 (1 year before Hangzhou city was liberated). In the quantitative analysis of this article, we use the same definition and explain it in detail. According to the 
administrative division in the late 1990s, 38 counties (and county-level cities) can be classified as guerrilla counties.

${ }^{11}$ For example, Long Yue, a former party secretary of Wenzhou and the commander and political commissar of the Southeast Zhejiang Guerrilla, was demoted to the position of party secretary of the Shanghai Turbine Factory in 1953.

${ }^{12}$ Before 1949, the guerrillas that were eventually incorporated into the Third Branch of Eastern Zhejiang Guerrilla were active in Cixi, Yuyao, and Yin. The Tieliu Branch was active in Haining, and the Jinxiao Branch of Eastern Zhejiang Guerrilla was active in Xiaoshan.

${ }^{13}$ The content related to the development of commune and brigade industries in the "May 7th Instruction" states, "Peasants of communes should mainly work on agriculture (including forestry, animal husbandry, side-line production, and fishery) but should also learn some knowledge about military, politics, and culture. When possible, agricultural collectives can also set up some small factories, while criticizing the bourgeoisie."

${ }^{14}$ Note that the ownership structure of Wenzhou's TVEs also varies across different regions. For example, the Liushi District of Yueqing (before the 1990s District was an administrative level between the county level and the township level) was the most developed area of private enterprises, whereas Hongqiao District was stronger in collective economy in the 1980s. Historically, the guerrilla cadres in Hongqiao maintained tight control over this area (after the 1970s all members of the CCP Committee of Hongqiao District were guerrilla cadres) and were thus able to control some economic resources in local governments. In contrast, the position of party secretary in Liushi District had long been held by southbound cadres or cadres from other towns of Yueqing. Guerrilla cadres served as vicedistrict-level (or below) officials for a long period. Nevertheless, local guerrilla cadres always protected the local interests, with the result that the district party secretary often found it difficult to control these local cadres and tended to have short tenures. These facts suggest that the difference in the local informal power configuration is important for understanding the historical differences in the ownership structure of TVEs.

${ }^{15}$ Due to the limitation of data, the reported number does not include the industrial output value produced by factories owned by villages and units below the village level. Although this would lead to an underestimation of the proportion of commune and brigade industries, we believe that the gross production value of commune and brigade industries in Kaihua would still be lower than that of other guerrilla counties, even when we take missing data into account.

${ }^{16}$ However, the cadres in Quzhou were more likely to be promoted by provincial-level leaders. For example, in the 1980s, several key leaders in the CCP Committee of Wenzhou were cadres promoted from Quzhou in the early years.

${ }^{17}$ We interviewed a number of grassroots cadres who were responsible for the management of bazaars in the 1970s. They stated that although their stated task was "to combat black markets," in reality their family members were trading in black markets.

${ }^{18}$ In the Liushi District of Yueqing, we interviewed a guerrilla cadre who stated, "Fortunately, I was not purged during the Cultural Revolution because I helped peasants find food to eat during the Great Leap Forward." This old cadre was also active in 
developing commune and brigade enterprises in the 1970s. Clearly, this was not because he had foresight of political movements, but because cadres who did not act in accordance with similar political logic were gradually eliminated in the tide of political movements. In fact, many guerrilla cadres surrendered to southbound cadres under political pressure (they were called "capitulators" in the local community). In order to please their superiors, they actively implemented extreme left policies. However, after the Great Leap Forward, the guerrilla cadres who implemented radical policies were not promoted. Due to the tensions with grassroots cadres and peasants, some cadres were purged in the "Four Clean-ups Movement," while others were denounced by the rebels during the $\mathrm{CR}$ and ultimately disappeared from the political arena.

${ }^{19}$ We calculated the per capita gross industrial output value of non-state-owned and nonforeign-invested enterprises by subtracting foreign-invested product value (including that invested by Hong Kong, Macao, and Taiwan) from the industrial output value of the nonstate-owned economy. In 1998, foreign investment in Zhejiang (including that from Hong Kong, Macao, and Taiwan) accounted for a relatively small proportion of the gross industrial product value and had limited influence on Zhejiang's economy. As a result, we put little emphasis on the role of foreign firms.

${ }^{20}$ In the late 1990s, Zhejiang launched a series of reforms to adjust administrative divisions so that many counties were merged into urban areas and the number of counties declined significantly after 1998. In order to avoid this problem, we only consider the data before 1998 .

${ }^{21}$ It should be noted that, as a critical juncture in history, the communist revolution can be seen as an exogenous shock. Therefore the strength of a local guerrilla can be regarded as an exogenous variable, which to some extent can mitigate the concern of endogeneity. To be sure, the probability of having revolutionary armed forces depended on many factors. By and large, revolutionary bases were located in less-developed and mountainous areas, yet not all poor and backward areas were able to establish a revolutionary base. For two adjacent regions with similar geographic features, whether a revolutionary armed force could emerge and persist was determined by many factors. Consider, for example, that southern Zhejiang was underdeveloped for a long time before its economic take-off during the CR. Even if some factors would lead to the emergence of a revolutionary base area, these factors did not produce economic growth in southern Zhejiang. In this sense, the potential causes for founding a revolutionary base area have little association with economic growth, and as a result, the emergence of a revolutionary base area can be seen as exogenous to economic growth. Moreover, if there had been an unobservable factor that affected both the establishment of a revolutionary base area and economic growth after the 1950s (but had no effect on economic growth in traditional agricultural society), we would be unable to explain the substantial variation of economic performance across revolutionary bases in China. Therefore, even if such a factor did exist, it would not exert a strong influence on economic growth after the 1950s.

${ }^{22}$ Note that a county could be liberated by the Third Field Army, the Second Field Army that later marched to Sichuan and Yunnan, or by local guerrillas. In some cases, local guerrillas collaborated with field armies in the course of liberating some counties. Thus various liberation patterns existed among the counties of Zhejiang.

${ }^{23}$ This variable is used to control for a county's land resources that could be developed into industrial development zones. 


\section{Competing interests}

The authors declare that they have no competing interests.

\section{Authors' contributions}

ML, TQ and QZ did the filedwork in Zhejiang province. ML and DZ did the analysis and drafted the manuscript. All authors read and approved the final manuscript.

\section{Acknowledgement}

We would also like to recognize the financial support provided by the China National Science Foundation (projects 71350002 and 71273012). All faults are solely ours.

\section{Author details}

${ }^{1}$ China Institute for Educational Finance Research, Peking University, Beijing, China. ${ }^{2}$ Department of Political Science, Northwestern University, Evanston, USA. ${ }^{3}$ China Academy of West Region Development, Zhejiang University, Hangzhou, China. ${ }^{4}$ School of Economics, Fudan University, Shanghai, China.

\section{Received: 25 March 2015 Accepted: 25 June 2015}

Published online: 06 August 2015

\section{References}

Acemoglu, Daron. 2006. A simple model of inefficient institutions. Scandinavian Journal of Economics 108(4): 515-546. Agricultural Bureau of Yongjia County. 1997. Agricultural annals of Yongjia county. Beijing: Ocean Press. Archival Bureau of Shandong Province. 2005. Southbound cadres. Beijing: Chinese Communist Party History Publishing House.

Bo, Yibo. 1991. Recall of a number of major decisions and events (book one). Beijing: Central Party School Press.

Cai, Hongbin, and Daniel Treisman. 2006. Did government decentralization cause China's economic miracle?". World Politics 58(4): 505-35.

CCP Committee of Xiaoshan County. 1957. Report on the case of a small number of members of agricultural communes requesting to quit communes by CCP committee of Xiaoshan, Internal Document, July 3.

Che, Jiahua, and Yingyi Qian. 1998. Insecure property rights and government ownership of firms. Quarterly Journal of Economics 113(2): 467-496.

Codification Committee of CCP Zhejiang Committee. 2007. History of Chinese Communist Party in Zhejiang. Hangzhou: Zhejiang People's Publishing House.

Codification Committee of Changshan County. 1990. County annals of Changshan. Hangzhou: Zhejiang People's Publishing House.

Codification Committee of Haining City. 1995. City annals of Haining. Shanghai: Chinese Dictionary Press.

Codification Committee of Huzhou City. 1999. City annals of Huzhou. Beijing: Kunlun Press.

Codification Committee of Jiangshan City. 1990. City annals of Jiangshan. Hangzhou: Zhejiang People's Publishing House.

Codification Committee of Jiashan County. 1995. County annals of Jiashan. Shanghai: Shanghai Sanlian Bookstore.

Codification Committee of Jinhua City. 1992. City annals of Jinhua. Hangzhou: Zhejiang People's Publishing House.

Codification Committee of Kaihua County. 1988. County annals of Kaihua. Hangzhou: Zhejiang People's Publishing House.

Codification Committee of Local History of Cixi City. 1992. County annals of Cixi. Hangzhou: Zhejiang People's Publishing House

Codification Committee of Local History of Ruian City. 2003. City annals of Ruian. Beijing: Zhonghua Book Company. Codification Committee of Local History of Yin County. 1996. County annals of Yin. Beijing: Zhonghua Book Company. Codification Committee of Local History of Yongjia County. 2003. County annals of Yongjia. Beijing: Annals Press. Codification Committee of Local History of Yuyao City. 1993. City annals of Yuyao. Hangzhou: Zhejiang People's Publishing House.

Codification Committee of Ninghai County. 1993. County annals of Ninghai. Hangzhou: Zhejiang People's Publishing House.

Codification Committee of Pinghu County. 1992. County annals of Pinghu. Shanghai: Shanghai People's Publishing House.

Codification Committee of Pingyang County. 1993. County annals of Pingyang. Shanghai: Chinese Dictionary Press.

Codification Committee of Quzhou City. 1994. City annals of Quzhou. Hangzhou: Zhejiang People's Publishing House. Codification Committee of Wenzhou City. 1998. City annals of Wenzhou. Beijing: Zhonghua Book Company.

Codification Committee of Wuyi County. 1990. County annals of Wuyi. Hangzhou: Zhejiang People's Publishing House. Codification Committee of Xiaoshan County. 1987. County annals of Xiaoshan. Hangzhou: Zhejiang People's Publishing House.

Codification Committee of Yiwu County. 1987. County annals of Yiwu. Hangzhou: Zhejiang People's Publishing House. Codification Committee of Yueqing County. 2000. County annals of Yueqing. Beijing: Zhonghua Book Company. de Mesquita, Bueno, Alastair Smith Bruce, Randolph M Siverson, and James D Morrow. 2003. The logic of political survival. Cambridge, MA: MIT Press.

Du, Runsheng. 2005. Self-narrative of Du Runsheng: documentary of major decisions on the rural institutional change of China. Beijing: People's Press.

Editorial Department of Industry and Commerce Administration of Quzhou City. 1995. Annals of administration of industry and commerce of Quzhou, Internal publication.

Editorial Department of Market History of Zhejiang Province. 2000. Market history of Zhejiang province. Beijing: Annals Press. 
Foster, Keith. 1997. Localism, central policy, and the provincial purges of 1957-1958: the case of Zhejiang. In New Perspectives on State Socialism in China, ed. Timothy Cheek and Tony Saich, 191-234. New York: M. E. Sharpe Inc.

Gandhi, Jennifer. 2008. Dictatorial institutions and their impact on economic growth. European Journal of Sociology 49(1): 3-30.

Gehlbach, Scott, and Philip Keefer. 2011. Investment without democracy: ruling-party institutionalization and credible commitment in autocracies. Journal of Comparative Economics 39(2): 123-139.

Hurst, William, Mingxing Liu, Yongdong Liu, and Ran Tao. 2014. Reassessing collective petitioning in rural China: civic engagement, extra-state violence, and regional variation. Comparative Politics 46(4): 459-482.

Kung, James, and Justin Yifu Lin. 2003. The causes of China's great leap famine, 1959-1961. Economic Development and Cultural Change 52: 51-73.

Li, David. 1994. Ambiguous property rights in transition economies. Journal of Comparative Economics 23: 1-19.

Liu, Yia-Ling. 1992. The private economy and local politics in the rural industrialization of Wenzhou. The China Quarterly 130: 293-316.

Magaloni, Beatriz. 2008. Credible power-sharing and the longevity of authoritarian rule. Comparative Political Studies 41(4-5): 715-741.

McGuire, Martin C, and Mancur Olson. 1996. The economics of autocracy and majority rule: the invisible hand and the use of force. Journal of Economic Literature 34(1): 72-96.

Nee, Victor. 2000. The role of the state in making a market economy. Journal of Institutional and Theoretical Economics 156: 64-88.

O'Brien, Kevin J, and Lianjiang Li. 1999. Selective policy implementation in rural China. Comparative Politics 31(2): 167-186.

Oi, JC. 1992. Fiscal reform and the economic foundations of local state corporatism in China. World Politics 45(1): 99-126.

Olson, Mancur. 1993. Dictatorship, democracy, and development. American Political Science Review 187(3): 567-576.

Organization Department of CCP Zhejiang. 1994. Materials of organization history of CCP Zhejiang province (1922.4-1987.12). Beijing: Daily Press.

Party History Research and Data Collection Committee of CCP Zhejiang Province, Political Department of Zhejiang Military Command of PLA. 1989. Zhejiang liberation. Hangzhou: Zhejiang People's Publishing House.

Party History Research Center of CCP Yongjia County, Agricultural Bureau of Yongjia County, and Archival Bureau of Yongjia County coedited. 1994. Origin of Chinese rural reform — practice of household responsibility system in Yongjia county, Zhejiang. Beijing: Contemporary China Press.

Peng, Yusheng. 2001. Chinese villages and townships as industrial corporations: ownership, governance, and market discipline. American Journal of Sociology 106(5): 1338-1370.

Putterman, Louis. 1997. On the past and future of China's township and village-owned enterprises. World Development 25(10): 1639-1655.

Qian, Yingyi, and Gerard Roland. 1998. Federalism and the soft budget constraint. The American Economic Review 88(5): 1143-1162.

Qian, Y, and C Xu. 1993. Why China's economic reforms differ: the M-form hierarchy and entry/expansion of the non-state sector. Economics of Transition 1(2): 135-170.

Qian, Yingyi, Barry Weingast, and Gabriella Montinola. 1995. Federalism, Chinese style: the political basis for economic success in China. World Politics 48(1): 50-81.

Qiu, Haixiong, and Jianniu Xu. 2004. Review on the role of local governments during the market transformation process. Sociology Research 4: 24-30.

Shi, Jinchuan, Xiangrong Jin, Wei Zhao, and Weidong Luo. 2004a. Institutional change and economic development: research on Zhejiang model. Hangzhou: Zhejiang University Press.

Shi, Jinchuan, Wei Wang, and Tao Qian. 2004b. Private economy and institutional innovation: research on Taizhou phenomenon. Hangzhou: Zhejiang University Press.

Shih, Victor. 2007. Factions and finance in China: elite conflict and inflation. Cambridge: Cambridge University Press.

Statistical Bureau of Zhejiang Province. 2000. Compilation of 50-year statistic materials of new Zhejiang. Beijing: Chinese Statistic Press.

Svolik, Milan. 2009. Power sharing and leadership dynamics in authoritarian regimes. American Journal of Political Science 53(2): 477-494.

Tao, Yu, and M Liu. 2013. Identify alliances of the 'harmonious society': intermediate associations, local elites, and collective petitioning in contemporary Chinese villages. In Elites and Governance in China, ed. Chien-wen Kou and Xiaowei Zang, 110-135. New York: Routledge.

The Office of the Agricultural Committee of China. 1981. A compilation of important documents of agricultural collectivization (book one). Beijing: Central Party School Press.

Tsai, Kellee. 2006. Adaptive informal institutions and endogenous institutional change in China. World Politics 59: 116-141.

Tsai, LL. 2007. Solidary groups, informal accountability, and local public goods provision in rural China. The American Political Science Review 101(2): 355-372.

Weitzman, M, and C Xu. 1994. Chinese township village enterprises as vaguely defined cooperatives. Journal of Comparative Economics 18: 121-145.

Wintrobe, Ronald. 1998. The political economy of dictatorship. Cambridge: Cambridge University Press.

Wright, Joseph. 2008. Do authoritarian institutions constrain? How legislatures affect economic growth and investment. American Journal of Political Science 52(2): 322-343.

Ye, Y. 2003. Peasants' quitting communes' trend after the climax of the cooperative movement in 1956-1957. Nanjing University Journal (Philosophy, Social Sciences, Humanities) 6: xx.

Zhu, Baojiong, and Peilin Xie. 1980. Tabulated index for monument records of Chinshihs in Ming and Qing dynasties. Shanghai: Shanghai Ancient Books Publishing House. 